
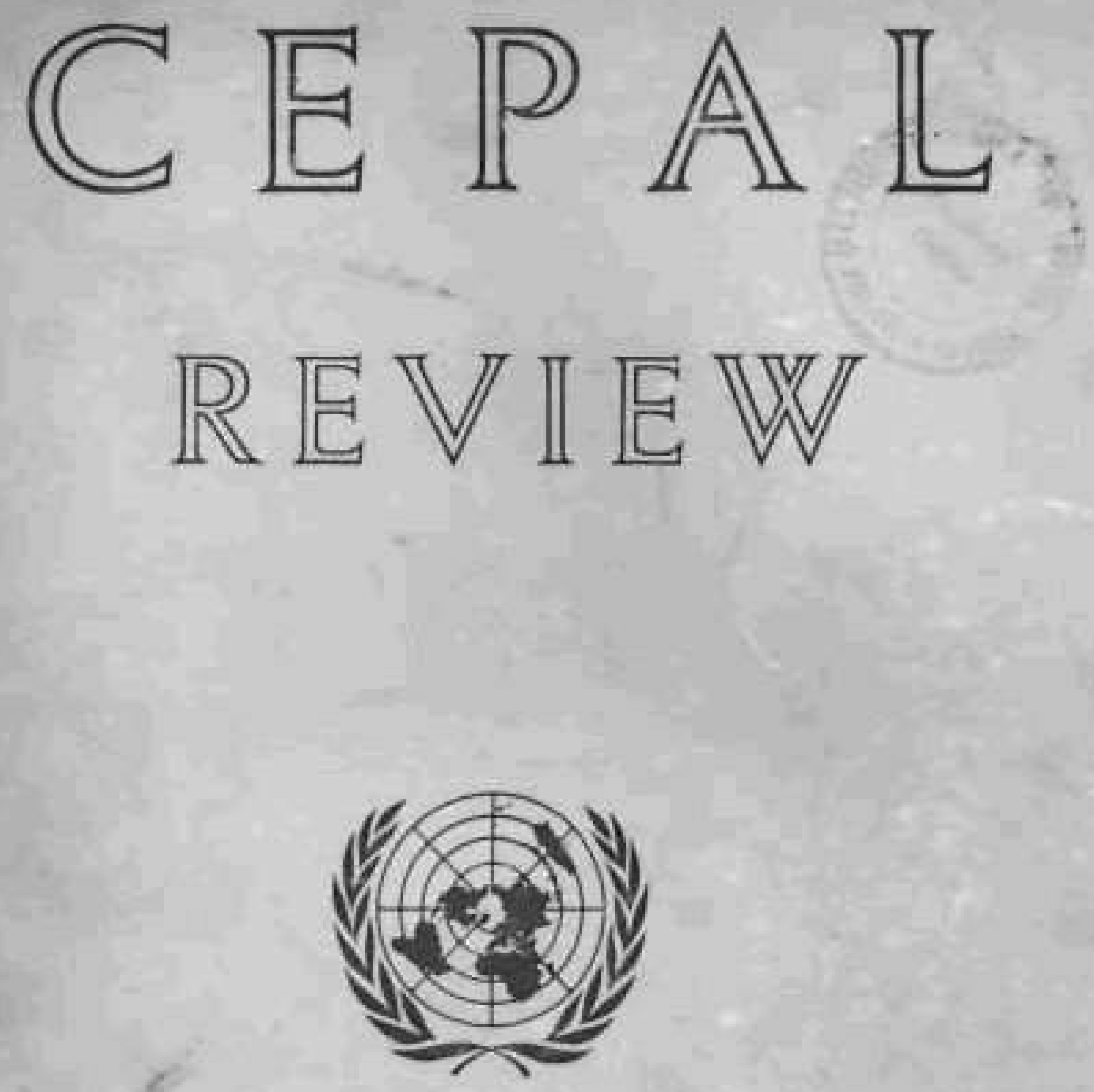

UNITED NATIONS

FIR S T SEM E S ER 1976 


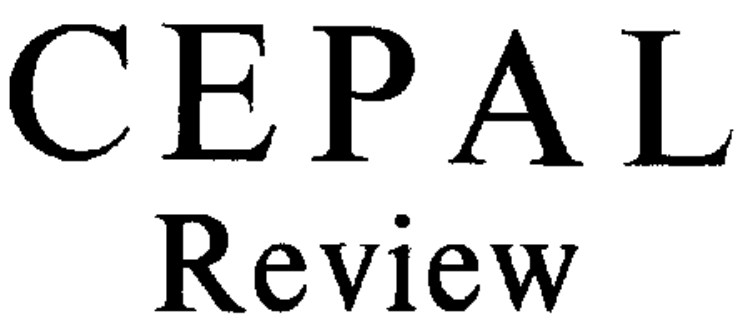

\author{
Director \\ RAUL PREBISCH
}

\title{
Technical Editor
}

ADOLFO GURRIERI

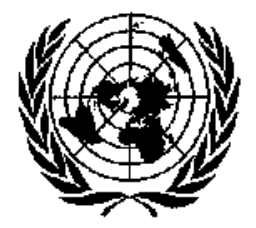

UNITED NATIONS

ECONOMIC COMMISSION FOR LATIN AMERICA

FIRST HALF OF 1976 


\section{CONTENTS}

A critique of peripheral capitalism

Raull Prebisch

Situation and prospects of the Latin American economy in 1975

Enrique V. Iglesias

Styles of development in Latin America

Anibal Pinto

Approaches to development: who is approaching what?

Marshall Wolfe

Power and development styles

Jorge Graciarena

Notes on integration

Cristóbal Lara Beautell

Some CEPAL Publications 
CEPAL REVIEW,

First half of 1976

Situation and prospects of the Latin American economy in 1975

\section{Enrique V. Iglesias*}

After describing the economic recession which came to a head in 1975 and examining some overall indicators, this article analyses the most important underlying causes of the recession. Two interrelated causes are particularly worthy of note: firstly, the deterioration of the economic situation of the centres, and secondly, the sharper contradiction between the growing demand for imports required by the prevail ing type of growth and the capacity to produce the foreign exchange necessary to pay for them and to cope with an increasing volume of financial services.

Lastly, some measures are suggested for dealing successfully with this critical situation, including (a) the establishment by the Latin American countries of a collective financial safety net to tackle their balance - of - payments problems; (b) the restructuring of the dymamic forces responsible for economic growth in the region, with emphasis on giving more of an impulse to the domestic market; (c) the strengthening and extension of forms of regional co-operation, and (d) determined joint action by the countries of Latin America at the international level. The article ends by reaffirming that Latin America's economic development problems are not only connected with achieving vigorous growth, but also with securing a more equitable distribution of its benefits.

"Executive Secretary of the Ecunomic Commis sion lor Latin America (CEPAL).

\section{Introduction}

In recent years there has been a series of interlinked international crises which are having a serious effect on the economic development of the peripheral countries in general and the Latin American countries in particular.

What is the significance of the changes we are witnessing? Are they merely of a transient nature, or are we moving towards much profounder structural changes in international economic trends? If this is so, then what role will the peripheral countries play and what policies should they adopt in order to fit in with the new situation and achieve the objectives pursued in their national development policies?

It is not simple to answer these questions, since the present time is full of uncertainties which make it very difficult to anticipate events or hazard hypotheses. Yet such is the challenging task that inspires the following remarks, which are based on the confident belief that Latin America has the vitality and capacity to take advantage of the opportunities which arise together with the risks.

\section{1. \\ The economic situation in 1975}

At the time of writing, at the end of 1975 , we have at hand the main figures which enable us to describe in broad terms the effects of the international economic situation on both Latin America and the central economies. I shall now give some basic figures so that we can draw some general conclusions from them. 
The initial estimates give the following picture of Latin America as a whole:

The rate of growth has gone down sharply, from 7 per cent in 1973 and 7.2 per cent in 1974 to 3.3 per cent in 1975 , according to the most reliable estimates.

- Exports of goods, expressed in dollars at current prices, went down by 6 per cent after having increased in the previous two years at an average rate of over 50 per cent. This slump in the growth of such exports - particularly noticeable in the nonoil-exporting countries- is to be attributed to a reduction of 7 per cent in the volume exported: this ended the firm growth trend of recent years and was only partly compensated by a modest increase of 1 per cent in the value of exports, which was in any case far below the rate of world inflation.

Imports of goods grew by only 6 per cent as against the increase of 40 per cent in the two preceding years. This figure reflects a drop of 7 per cent in the physical volume of imports (for the non-oil-exporting countries the drop was 9 per cent). In contrast, the values of imports rose by 14 per cent, which shows how serious are the effects of world inflation on the economies of the region.

- The terms of trade deteriorated by 11 per cent, which is serious when it is remembered that this indicator had already gone down by 10 per cent in each of the preceding two years for the non-oil-exporting countries as a whole.
The purchasing power of exports dropped by 17 per cent in 1975 with respect to the preceding year as a result of the combined effect of the unfavourable terms of trade and the drop in the volume of exports.

The trade balance of the 19 non-oilexporting countries will show a deficit of 10.3 billion dollars as against 9.2 billion in the previous year. If we add to these figures the deficits in respect of net payments of profits and interest, then the total current account deficit will be 15.2 billion dollars as against 13 billion in 1974 . The oil-exporting countries of the region, for their part, will have a current account surplus in 1975 of only about 2.8 billion dollars, which is far below the 6.4 billion dollars recorded in 1974.

The balance of payments of the nonoil-exporting countries will show a deficit of close to 2.5 billion dollars, since the compensatory and noncompensatory capital flows will be insufficient to finance the current account deficit. All this will obviously have the effect of reducing the net reserves of these countries,

We do not yet have any figures on the behaviour of other internal variables of the regional economy, but we do know that these figures vary significantly from one country to another, not only between the oil-exporting countries and non-oil-exporting countries, but also among the latter, since their particular foreign trade structures create different capacities for facing the effects of the world situation.

In any event, for the great majority of the countries the above figures do 
reflect the upheaval caused by the international economic situation and its inevitable impact on the rate and structure of domestic growth.

The forecasts for the coming year are varied, and once again reflect the great diversity of specific cases.

There are those who feel that the situation will become even more difficult because of the slow reaction of the centres to the measures designed to promote the economy, and the scanty reaction of prices and markets to the signs of recovery shown by some industrial economies, Furthermore, indebtedness has increased and the conditions on financial markets have become more difficult, particularly for countries without experience in tapping resources from such markets.

Others, in contrast, consider that the most difficult time is over and that the recovery of the centres will rapidly spread to world trade as a whole.

Whatever the hypothesis accepted, the situation will continue to be difficult, so that knowledge of the international economic situation and its projections for the central economies is of particular importance to our region

There are some significant indicators for the industrialized countries which enable a general picture to be drawn:

The rate of growth of the member countries of the Organization for Economic Co-operation and Development (OECD) will be slightly over 1 per cent according to calculations made by the technical secretariat of the Organization, since the recovery noted in the second half of 1975 will compensate for the contraction observed in the first part of the year. It should be recalled that these countries had a zero growth rate in 1974, and that the average annual rate recorded in the last ten years was 5.5 per cent.

The timing of the recovery in the various industrialized countries differs considerably. The United States, Japan, and probably Canada are the countries which are now showing the biggest degree of economic recovery. Germany and France are in an intermediate position, while Italy and the United Kingdom will probably only overcome their negative growth rates from 1976 onwards. Even in the countries of the first group, however, there have been some contradictory signs in recent months as regards the steadiness and dura bility of the recovery, and this has given rise to certain doubts about the future course of the recovery process, especially in the case of the United States economy.

Industrial production at the beginning of 1975 was 20 per cent below that recorded one year earlier, and it only began to recover quite sluggishly after the accumulated stocks of manufactures had been used up.

- Unemployment continued to be marked, and in many cases the rates of unemployment were the highest for the last 20 years. According to II.O, in September 1975 there were 17.1 million unemployed in the industrialized economies, and it is estimated that the figure might rise to 18.5 million by the end of the year.

- The levels of domestic prices may be assessed from different standpoints. 
On the one hand, the stabilization policies and the effects of the economic recession itself checked the rate of growth of domestic inflation and the rate for the OECD countries dropped to around 10 per cent as against the average of 13 per cent recorded in 1974. On the other hand, however, the new basic or minimum level of inflation, which appears to be situated around 8 or 9 per cent, is nevertheless twice that considered acceptable at the beginning of the decade and is subject to many tensions which still make it unstable and capable of rising rapidly in response to the reactivating surges of domestic policies.
In the external sector the economies of the OECD countries showed a current account deficit of close to 20 billion dollars, a figure considerably lower than that of the year before and also below the pessimistic forecasts of the beginning of the year. On the other hand, however, it contrasts with the surpluses of 10 to 15 billion dollars recorded at the beginning of the decade. Even so, it is noteworthy how the central economies have found it relatively easy to finance their current account deficits, which created so much concern when the rise in oil prices was first announced.

This situation has had secondary effects which are worth noting, however.

Table I

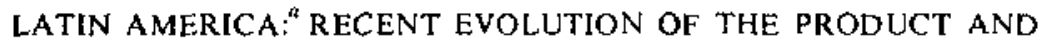

THE EXTERNAL SECTOR

(Percentage variation)

\begin{tabular}{lccc}
\hline & 1973 & 1974 & 1975 \\
\cline { 2 - 3 } $\begin{array}{l}\text { 1. Gross domestic product } \\
\quad \text { (at constant prices) }\end{array}$ & $7.2^{\mathrm{h}}$ & $7.0^{b}$ & $3.3^{\prime}$ \\
2. Exports of goods (value in millions & & & \\
$\quad$ of dollars at current prices) & 44 & 68 & -6 \\
3. Unit value of exports & 35 & 65 & 1 \\
4. Volume of exports & 7 & 2 & -7 \\
5. Imports of goods (value in millions & & & \\
$\quad$ of dotlars at current prices) & 31 & 71 & 14 \\
6. Unit value of imports & 18 & 40 & -7 \\
7. Volume of imports & 11 & 23 & -11 \\
8. Terms of trade & 14 & 18 & -17 \\
9. Purchasing powcr of exports & 22 & 21 & \\
\hline
\end{tabular}

Soturce: (EPAl. on the basis of official statistics.

23 countries.

-19 countries.

'Preliminary estimate on the basis of dala for 13 countries. 
On the one hand, the central economies are absorbing external resources on the international capital markets, so that their needs and demand have come to compete with those of the non-oilexporting developing countries. Almost simultaneously, they have restricted their transfers of public capital to the developing world and in particular to those who form the middle class in that world, i.e., the Latin Americans. As a result of these external restrictions the industrial economies have had to be much more cautious in their own domestic reactivation policies.

In broad lines, such is the present picture of the central and Latin American economies. Now let us see what reflections are called for by this evolution on the international situation if we consider it in the light of the figures for 1975 but look a little further and place the phenomena within the framework of the trends which have clearly been developing in recent years at the international level.

Table 2

LATIN AMERICA:" BALANCE OF PAYMENTS TRENDS

(Millions of dollars at current prices)

\begin{tabular}{lrrr}
\hline & \multicolumn{1}{c}{1973} & \multicolumn{1}{c}{1974} & \multicolumn{1}{c}{$1975^{8}$} \\
\cline { 2 - 4 } 1. Trade balance & 1250 & 2100 & -4000 \\
2. Balance on current account & -3765 & -6610 & -12470 \\
3. Final balance of payments position & 3690 & 3840 & -390 \\
\hline
\end{tabular}

Source: CEPAI., on the basis of official statistics.

23 countries.

'Preliminary estimates.

2.

Looking beyond the immediate situation: the end of an epoch

The various signs which have characterized 1975 - almost all of them negativesignify something deeper and more serious than the cyclical pauses or setbacks which have alfected the world and Latin American economies more than once since the war.
This realistic evaluation makes it necessary to explore the roots, principal manifestations and prospects of the situation facing Latin America, both at the world and the regional level.

I should like first of all to take up the international dimension or more 
specifically, the industrialized market economies which form the centre of the capitalist economic system.

Recent events have brought out once more the decisive or dominant influence of what takes place in this nucleus of countries, and have confirmed the dependent nature of the evolution of the periphery. The obvious exception of the oil market, which in any case is a very new development, does not alter in any way this rule of operation of the world system.

The central nations therefore bear the outstanding and unavoidable responsibility in the contemporary processes. This is a simple fact: it is not an accusation or an excuse, and still less is it any kind of renunciation of our responsibility to take decisions and carry out tasks ourselves. But the world we live in was organized in this way by separate and successive ruling powers, not in their own image and semblance but in accordance with their own convenience. We are very far from thinking that all the great problems of the periphery derive from this circumstance, and still less do we believe, as has sometimes been suggested, that the underdevelopment of some countries - the majority - has been at once the cause and the principal effect of the progress of the fortunate few. Anyone who studies the industrial revolution can question this exaggeration. Even so, after all the reservations and due consideration of the matter, the situation of subordination and the unequal relations between the centre and the periphery remain an evident truth.

On the other hand, it must be frankly admitted that anxieties and doubts about the solidity and durability of the system which is now in crisis have been coming to the fore for some time past in the more enlightened circles of the industrialized centres. The contradictions of the opulent society; the precariousness of dynamic growth based to a large extent on the excesses and waste of the drive to consume; denunciation of the myth of mere growth for its own sake, the increasing anxiety about the degradation of the environment and the spoliation of natural resources and common assets, and the emphasis on the "quality of life", show that the exceptional economic boom of the preceding period did not eliminate the capacity for critical reflexion.

It is scarcely necessary to stress the importance of this, especially in the evaluation of future prospects and actions. Consequently, in contrast with other past situations, there are very few today who yearn for or support the return or reconstruction of the world of yesterday.

If all this is evident and significant for the nations which occupy a privileged position, then how much more so is it for the periphery. The present crisis has dispelled the illusion that the relatively favourable trends which prevailed until a short time ago in the world economy were deeply rooted and promised steady, uninterrupted expan sion. Critical reflexion and preparation for the world of tomorrow are therefore more imperative than ever.

It would be vain to try to make an exhaustive examination of the elements which have shaped the present situation of the industrialized economies and, as 
a result, the trends and features of the world panorama. As we have pointed out, there is a clear crisis of diagnoses and remedial measures. Most economists admit that we are in a post-Keynesian situation, but we are still very far from understanding fully the fundamental lines of the new situation, and even further from suitable policies to deal with it.

What seems beyond doubt and must be taken as the starting point for any analysis is that we are faced with a crisis of a new type which cannot be interpreted or solved by taking as our guide the examples and practices of the past.

Naturally, many current symptoms and factors are also common to other equally serious contingencies: economic recession, unemployment, acute disequilibria in the balance of payments, con- traction of international trade, excessive inflationary or deflationary swings, etc. These are familiar ingredients in the history of these situations of change.

The theoretical analyses, regardless of whether they come from liberal, marxist, classical, neo-classical or heterodox sources, provide us with many useful and fertile approaches and categories, but in various ways and to various extents even their most flexible and objective approaches show a certain inability to capture the substance of the new situation which is arising and to define appro priate action.

Rather than proposing other hypoth eses or drawing attention to those which seem most valid, we are interested above all here in bringing out those aspects of the emerging picture which most affect the countries of the periphery and in particular those of Latin America.

The dynamism of the centres

First of all, we should bring out those aspects which affect the rate and type of growth of the central economies.

Here, the combination of the stagnation of productive activity with persistent inflation - the familiar and so often discussed "stagflation" undoubtedly constitutes the most outstanding factor. This unusual mixture of circumstances has a dual impact with extremely serious repercussions for the developing world.

On the one hand, the developing countries must suffer the effects of this loss of dynamism on international trade and, more specifically, on the volume, value and composition of their own exports. It is reasonable to assume, for example, that the developing countries will have greater difficulty and fewer opportunities for pursuing the process of diversification of their exports which has been undertaken with such promising results in recent years.

On the other hand, the developing countries suffer from the effects of inflation in the industrialized economies through the continuously rising prices of the imported equipment and inputs which are vitally needed for fuelling their development.

While the first element reduces their purchasing capacity abroad, the second increases the magnitude of the payments 
they must make and consequently increases their financing problems. The figures presented in this connexion clearly show the consequences of this phenomeenon for Latin America's external economic relations.

\section{Uncertainty about the future}

From another point of view, there is great anxiety as a result of the generalized uncertainty about the prospects for the near future and the way and degree in which the progress of the developing countries will be affected. There are certain contradictory aspects here which have to be borne in mind.

On one hand, despite the difficulties raised by the increase in the price of oil and its very considerable effects - which initially gave rise to alarming forecasts - the truth is that the central economies have nevertheless managed to avoid sliding towards a state of crisis like that of the 1930s. Despite the high levels of unemployment and economic stagnation, and the reduction or reversal of growth rates, it has been possible to keep a certain essential grip on events. Indeed, it should be noted that it has even been possible to keep the deficits stemming from the increased oil costs at a manageable level, mainly by absorption of the surpluses of the oil-producing countries.

This reality, however, goes hand in hand with another to which we already referred: i.e., not even the most optimis tic forecasts assume that there will be a return to the rates and types of growth of the industrialized countries which were recorded in the decade ending in 1973-1974.

As regards the possible rates of expansion, there are various factors which appear to contribute to keep them low.

One of these is the stubborn persistence of inflationary pressures which threaten or tend to frustrate the efforts made to reactivate the production systems. In addition, there is a fear in some countries that greater reactivation might bring with it a deterioration in the already precarious balance-ofpayments situation.

\section{Our position as a "competing middle class"}

Another aspect of the emerging panorama which has a considerable effect on the periphery in general and our region in particular is the resurgence of protectionist tendencies in the industrialized countries and the new attitude to Latin America's position in the international community.
Although the international markets are more open to the industrial exports of developing countries, the signs of recession displayed by the central economies are cause for concern.

The internal and external crises of these economies have led to the closing of markets for certain commodities 
(meat is a conspicuous example) and have given rise to barriers to exports of non-traditional industrial products. Once again there is jealousy over competition or internal pressures endangering the achievements - which we believed had been firmly established - in the field of international co-operation for which we had worked so long.

A point which has even greater implications for the future is the growing tendency to consider Latin America as the "middle class" of the international community.

In a world which is going through a difficult economic situation, the ma chinery for the transfer of resources diminishes in its scope and is oriented preferentially towards the countries of least relative economic development, thus ruling out almost completely the countries of Latin America. This is not to criticize the measure as such, but in the absence of corresponding measures to take care of countries like ours which are in an intermediate stage of development. Latin America must fall back on its own capacity for tapping resources on international financial markets rather than on sporadic grants and transfers.

There are other elements, however, which are just as important as those referred to, such as the levels of unemployment which seem to be coming close to the maximum acceptable social and political limits or even to have exceeded them, according to the data in the recent It. report mentioned above.

It will be readily understood that this state of affairs not only affects domestic political relationships, but also has obvious international implications. Greater energy and more concerted measures in reactivation policies would therefore be desirable and the most recent meetings of the highest authorities of the central countries are witness to this. However, the majority of forecasts loresee only a modest recovery in the coming years, and there are many who add that this recovery will not be of a stable nature and will be marked by continuous bouts of inflation.

\section{The quality of growth of the central countries}

Other important queries for the countries on the periphery stem from criticisms of the development model of the industrialized economies or concern the stages which are discernible in their future.

The increasingly widespread criticisms of what has been called the myth of development at any price may reduce the global dynamism of the system. The emphasis being placed on the quality of life, defence of the environment, protection of natural resources and common assets, greater equity in the distribution of well-being and other objectives which are beginning to form the new development ideology of the present time can and must involve significant changes in the patterns of demand and assignment of resources.

The course of this process is still uncertain, and its repercussions on the periphery are even more so. We should nevertheless think deeply about it and strive to adapt ourselves flexibly and 
imaginatively to the new structures and arrangements which a new pattern of international division of labour will tend to establish for some countries.

\section{The Latin American panorama}

\section{The new Latin America}

Latin America is in a position to meet the challenge represented by this change in international conditions. The fact is that the existence of urgent social problems and the flood of critical comment on various serious weaknesses in the development of the region have sometimes caused us to overlook the great positive changes which have taken place in the period we are now leaving behind us.

Thus, even if we accept all the legitimate reservations and criticisms made, there is nevertheless an impressive positive balance as regards the changes which have taken place in the dimensions and structure of the Latin American economy. As was pointed out in a recent CEPAL publication ${ }^{1}$, in 1950 the total product of the region (in 1970 dollars) amounted to some 60 billion dollars. In 1974 it had increased to 220 billion dollars, i.e., almost four times the size of the regional economy in 1950. If the recent rate of Latin American development is maintained for the next decade, the region's productive system will grow to twice its present size and about seven and a half times its size in 1950, i.e., about as big as the economy of the European Economic Community in 1960.

'Latin America: the new regional and world setting, Cuadernos de la CEPAL series, No 1 , Santiago, Chile, 1975.
According to the same source, in 1950 , the manufacturing product was around 11 billion dollars, but in 1974 it was almost five times greater, and its share in the total product rose from 18 per cent to 24 per cent between those years. Finally, in 1950, industrial exports represented 6 per cent of total exports and were limited to a few specialized products, while in 1974 they accounted for 18 per cent of foreign exchange income and covered a wide range of manufactures.

Of course, this overall view takes no account of some very appreciable national differences. Although the bigger countries account for the lion's share, except in a very few cases the winds of change have been felt throughout the region.

Moreover, this overall conception of Latin America - of this other Latin America - corresponds to a reality and a necessity.

It corresponds to a reality, because despite all the disappointments, doubts and limitations encountered in the process of regional integration, the political, institutional, cultural and economic conditions have unquestionably evolved towards a greater degree of association and not towards greater dispersion than existed 25 years ago. And this has been so in spite of the fact that the differences between countries and groups of countries have become 
more accentuated. The great diversity or plurality has thus not been an obstacle to this great historic progress.

It also corresponds to a necessity, because in this world of superpowers and powerful regional conglomerates, the new dimensions, structure and links which characterize our region are an essential condition for increasing its bargaining power and strengthening and expanding its development potential.

\section{The impulses and pressures affecting Latin American development}

Before assembling some ideas on the challenges posed by the present international situation and prospects, it is worth identifying the influences or forces which are behind those changes, in order subsequently to set about an analysis of the adjustments or changes which appear to be called for by the panorama which is opening up before our eyes.

In the past, the dynamics of Latin American development have depended fundamentally on a set of impulses and pressures whose main components have been domestic demand, foreign trade and the regional market. As a background to all this, there have been the changes in the level and distribution of income: an aspect to which I shall refer later.

The elements in question have operated and combined in very different ways in the course of a process whose various stages can be classified in accordance with some well-known categories identified in the "CEPAL philosophy".

Little reference need be made to the phase which we may call "outwardlooking growth", which extends for most of Latin America up to the great crisis and in which the external demand for primary commodities constitutes the main (and often the only) factor of dynamism.
Various phases may be distinguished in the period which began with this point. Following the still-valid criteria of an CEPAL study made ten years ago", these phases are as follows:

The first phase, which extended up to the early post-war years, was one of absolute foreign trade restrictions which exerted pressure (particularly in the countries of greatest relative diversification and sufficient size of market) towards industrialization. Such industrialization assumed a directly substitutive nature as a result of the pre-existing demand and the social composition of the economy.

The second phase, which was one of relative restrictions, extended from the end of the $1940 \mathrm{~s}$ up to the middle of the 1950s. In the course of it, the external circumstances improved and were combined with the continuation and diversification of the efforts to indus trialize in much of the region. The end of the Korean war put an abrupt stop to this phase, although it carried on a little longer in some countries such as Brazil.

\footnotetext{
"CEPAL, "The growth and decline of import substitution in Brazil", Economic Bulletin for Latin America, Santiago, Chile, Vol. IX, No I, March 1964, pages 1.62.
} 
The third phase lasted up to approximately the beginning of the second half of the 1960s. In this phase, the relative restriction of the external sector got worse and the problems of the balance of payments and of indebtedness became more serious. At the same time, the internal impulse for industrialization diminished, partly because of the limitations on the capacity to import, but mainly because of the obstacles encountered in the advance towards new fields of manufacturing, where market size became a decisive element. Only Brazil, and to a lesser extent Argentina and Mexico, succeeded in crossing this frontier and keeping up the dynamism in industrialization. In other words, in this phase the dominant themes are stagnation and balanceof-payments fluctuations. It is important to note, however, that this phase saw the crystallization of the first regional integration projects, which were due largely to the search for other elements which could impel development and which in some areas, such as Central America, represented a decisive step towards initiating the industrial transformation process.

The fourth and last phase coincides almost exactly with the last ten years, culminating in the years 1973-1974 and running into crisis between 1974 and 1975. This, as we have termed it in CEPAL, is the period of "internationalization" of the Latin American economy and in particular of the economies of the countries of greatest relative development of the region.

Thus, it is mainly exogenous elments which have impelled and guided the growing development. This has been due to a combination of a vigorous demand for primary commodities; a marked improvement in the terms of trade between 1971 and 1973; the increasing and dominant participation of transnational enterprises, especially in sectors involving greater diversification of the industrial spectrum; the circulation of big financial flows which have taken various forms; and finally participation in increased exports of manufactures, which have come to play an important role in the expansion of some activities.

On the other hand, of course, the impulses coming from the domestic market and regional demand also increased, although at a slower rate. It should be borne in mind that Latin America absorbed almost one-third (32.8 per cent) of its own exports of industrial products in 1970-1974, and the value of these exports rose from some 850 million dollars in 1970 to almost 2.3 billion dollars in the latter year.

If we take account only of the external factors, then it could well be maintained that the phase which is now coming to an end was equivalent to a new and more complex version of the "outwardlooking growth", although it would be truer to say that it was both towards the exterior and from the exterior. If we consider the other elements, however, we see that this characteristic was combined with "inward-looking" impulses not only in the individual economies, but also in the regional sphere. We are therefore dealing with a broader and manyfaceted form in which the relative weight of the various dynamic elements identified has been considerably changed. 


\section{The relations between industrialization and foreign trade}

Before examining some primary causes of the crisis of this model I think it would be useful to review this experience in the light of the various CEPAL approaches which have given rise to much discussion and some misunderstandings, and particularly the relations between industrialization (or, if it is preferred, substitution industrialization) and foreign trade.

The above review of the outstanding phases of Latin American development enables us to see that the greater or lesser openness of the process of industrial diversification depends to a very large extent on the circumstances created by the international economy and, more specifically, by the central countries. This does not mean that we are overlooking the significant advances made in the handling of short-term policies, the administration of relative prices and especially exchange rates, the promotion of exports, and the enterprising spirit of a small sector of national businessmen, or overlooking the role played in this opening of the industrialization process by the transnational enterprises. One way or another, however, it is the behaviour of the international economy which has facilitated and sometimes even made possible the crystallization and consolidation of all these efforts. Substitution industrialization, even in its "closed" phases, constituted a necessary and vital precondition for the subsequent opening.

There can be no doubt that at the beginning of the process not enough consideration was given to the opportu nities for exporting manufactures in the future, nor was this element given its proper value in the assignment of resources or the selection of activities. Several critics have gone into this matter at length and have concluded that the promoters of substitution industrialization had autarkic leanings.

This is not so, however. The truth is that these concerns were outside the historical and objective framework within which the problem was posed, what was really in question at the time being the very purpose of industrialization.

From this point of view, it seems strange or paradoxical that these criticisms sometimes came precisely from those who had little faith in the viability or desirability of this central purpose or else were actually opposed to it.

Thus, if some were guilty of pessimism or of underestimating the need for opening up industrialization efforts to the exterior, there can be no doubt that others were guilty of scepticism about the very need for industrialization.

As the United States economist Stefan H. Robock noted some little time ago, often a false dichotomy is created between industrialization through import substitution and industrialization through export industries ${ }^{3}$. In reality,

\footnotetext{
${ }^{3}$ Stelan H. Robock, "Una dicotomía falsa: industrialización a través de la sustitución de importaciones o mediante industrias de exportación", El trimestre económico, Vol. XXXIX (3), N* I55, Mexico City, JulySeptember 1973.
} 
however, the industrialization process is not divided up in this way: substitution industrialization can and must be integrated into the process of opening up to the exterior, and this is what has been tak ing place recently in Latin America.

In reality, despite its setbacks and even distortions, the regional experience corresponds closely to that of countries which became industrialized at a late date: those which achieved this when the centre periphery system based on the classic nineteenth century scheme of the international division of labour had already emerged. Robock had the following to say about the industrial experience of a certain country:

"For example, this country first of all imported manufactured goods from more highly developed countries, then began to produce its own substitutes, and finally built itself up into an exporter of the same products. To begin with, the exports... of manufactured products tended to go to less developed countries... but later it became able to export to industrially more advanced countries in proportion as its labour force gained skills through experience, the quality of its products improved, and the commercial skill of its businessmen became more sophisticated"4.

Stefan Robock was not referring to any of the most industrialized Latin American economies, however, but to the case of Japan.

\section{The present style of development at the crossroads}

What we must discuss now are the apparent primary causes of this crisis.

Only a brief and tentative approximation in this respect is possible for the time being.

To start with, there is no need to reiterate that the decisive element in this state of afiairs has been the abrupt change in the external situation; but attention should be paid, however, to a less obvious aspect connected with one facet of the "growth structure" in the recent period: i.e., the relationship between overall development and the external sector.

With regard to this matter of cardinal importance, a CEPAL study stated that "up to 1965, the average growth of imports was 0.4 times that of the product"; i.e., if the annual growth of the product was 6 per cent, the corresponding increase in imports was 2.4 per cent. From 1965 up to 1973 , however, "the ratio between the two types of growth rose to an average of 1.3 "; so that the same annual rate of increase of 6 per cent in the product now gave an increase of 7.8 per cent in imports ${ }^{5}$.

Going more deeply into the same point, the study indicates a further factor which aggravates the situation: the coefficient of elasticity of total

${ }^{4}$ See Stefan H. Robock, op. cit., pp. 524 and 525 .

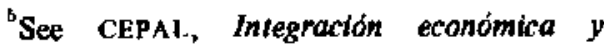
sustitución de importaciones en Américo Latina, by Juan Ayza, Gérard Fichet and Norberto González, Fondo de Cultura Económica, Mexico City, 1975, p. 52. 
imports with respect to the product increases in relation to the growth rate. This means that not only is the coefficient of elasticity greater than unity and therefore imports tend to grow more rapidly than the product, but this situation gets worse in proportion as the growth rate increases, since the coefficient of elasticity itself also increases ${ }^{8}$.

As we can see, then, the last phase of Latin American development was marked by a contradiction which was either latent or eise exerted great influence in the evolution of recent decades and has been a standing concern of CEPAL, namely, the more or less pronounced imbalance between the demand for imports generated by and characteristic of the structure of a particular type of growth and the capacity of that same structure to generate sufficient foreign exchange to pay for imports of goods and the rapidly increasing financial services of various types.
Looking at this problem from another angle, it could be suggested that the opening towards the exterior or the "internationalization" of the Latin American economy went beyond the limits permitted by its place in the international division of labour, despite the obvious progress made in such significant aspects as the export of manufactures.

Of course it is also legitimate to argue that it is not this process of opening which has made our economies more vulnerable, but rather the drastic changes which have taken place in the international situation.

In view of the difficulty of giving a decisive judgment on the matter it can only be said that the existence of both these circumstances makes it necessary to give more attention in future to the vulnerability of development schemes to the structure of their external relationships.

3.

\section{Future Tasks and Prospects}

The prospects for the immediate future, both at the world and regional levels, suggest that Latin America will have to act on various fronts simultaneously:

- Coping pragmatically with the period of transition;

- Setting about the rearrangement of the forces which have kept up the

'Ibid., chapter II. process of economic growth in recent years;

- Exploring and developing new potential forces through renewed machinery for co-operation between the countries of the area;

Acting with unity and initiative in the shaping of the new international economic order. 


\section{The period of transition}

This rearrangement is faced with an obstacle created by the difficulties of the present period of transition, arising from the balance-of-payments disequilibria of the vast majority of the countries of the region.

It could not reasonably be hoped that the adverse effects of an economic recession as acute as that which is affecting the central countries could fail to have palpable effects on the rate of growth of Latin America. The fundamental problem, as always, is that of relative levels. We must try to determine how far it is possible to minimize these effects so as to keep their influence on the rate of employment and domestic activity within politically and socially acceptable levels.

The recent economic experience of the non-oil-exporting countries has clearly shown that all governments have been obliged to face up to the need to make serious internal adjustments in their economies in order to absorb the impact of the international situation, and in particular the impact of the high oil prices, international inflation and changes in external trade.

The various individual countries face similar problems but are in very different situations as regards dealing with them, either because of the different structures of their foreign trade, their particular endowments of natural resources, or the range of economic policy instruments which they have at their disposal.

Generally speaking, however, they all must make choices, which are not always compatible, between a high rate of growth of the product, an acceptable trade deficit, an economically and politically acceptable level of indebtedness, and a low rate of inflation. The selection of certain objectives naturally clashes with other objectives. It is possible to maintain a high rate of growth of the product by sacrificing objectives in the field of prices, but this will undoubtedly clash with objectives related to the trade deficit and external indebtedness, and so forth.

There are no universal solutions. The countries will have to continue operating within the margins of pragmatic choices. In order to do this, they can now draw on much richer and more flexible experience in the handling of economic policy instruments such as exchange rates, tax and tariff machinery, monetary policies, and possibilities of access to international financial markets.

This has made it possible to surmount the serious difficulties of 1975 at a cost much lower than that at first estimated. The same thing will have to be done in the next few months, while waiting for the recovery of the markets or the reaction of the various elements of the international machinery, which, it may be noted in passing, have shown themselves to be equally dynamic and imaginative.

Conscious of the acute balance-ofpayments problem which faces all the countries alike, the CEPAL secretariat suggested at the sixteenth session of the Commission" the possibility that the region might try its own formula of collective financial security with the

\footnotetext{
${ }^{7}$ Port of Spain, 6 to 14 May 1975.
} 
backing of the central countries with which Latin America has trade relations.

This move, the study of which was approved by governments and is now taking place at the level of the central banks of Latin America, had a dual purpose. Its primary purpose was to draw attention to the special balanceof-payments position of the region in the present economic situation with a view to a new effort for collective regional co-operation in the financial field. Its second purpose was to introduce this initiative into the international dialogue in view of the interest in sustaining the rate of imports of the countries of the region during the present crisis period for the sake not only of Latin America but also of the central exporting countries.

Even if the discussion of this subject serves only to draw attention to the special balance-of-payments problems of the region and to induce the industrialized countries to give them consideration, it will have carried out a by no means negligible role.

\section{The rearrangement of the forces which have sustained the process of economic growth in the past}

In view of the foregoing, the future prospects for the economic growth of the region will depend largely on the rearrangement of the forces which have sustained such growth in the recent past. This is not only an urgent need in the present circumstances but also a great opportunity for the whole region and in particular for the countries of higher development.

In sum, the problem is basically that of giving new dimensions to the role of the domestic market without reducing the dynamism of exports to the rest of the world and in particular to the Latin American region.

The relative weight of each of these forces - i.e., the domestic market and the external market - is considerably influenced by the size of the national economy. Thus, for the countries of less relative development the ratio of their domestic market to the capacity for external expansion, particularly as regards exports to the other countries of the region, will continue to be greater than in the case of the more developed economies.

For this reason, it is necessary to reassert the conviction that in the phase which is just beginning now there will be a considerable increase in the significance of the Latin American market, and ultimately of the integration process. As was stressed in a document mentioned earlier ${ }^{8}$ :

"The possibilities and viability of this objective are clear, in view of the large size and greater diversification of the Latin American economic spectrum. Although in the mid1950 s - when the integration projects were launched - the productive structures perhaps lagged behind the possibilities opened up, the present situation is quite different, and the actual facilities

\footnotetext{
${ }^{8}$ See Latin America: the new regional and world setting, op. cit.
} 
are fully in keeping with these objectives".

Some figures about the Latin American trade in manufactures were given above. The example of Brazil is particularly interesting in this respect, since between 1970 and 1974 its industrial exports to the region increased from some 221 million dollars to almost 780 million, and on average, during this five-year period, Latin America's share came to a little under 30 per cent.

In the CEPAL study on the possibilities of the efficient substitution of imports at the regional level to which reference has been made ${ }^{9}$, emphasis was placed on the volume of imports needed to supply the region with chemicals and capital goods.

In the period 1972-1973, these two items represented 68 per cent of the total imports of the region and had a value of approximately 16 billion dollars. Projections for 1985 indicate that Latin America's imports of machinery and equipment alone could come to around 24 billion dollars in that year. This represents a potential market for which substitution processes of international-level efficiency and competitiveness could be carried out; moreover, there are grounds for hoping to go beyond the regional market to the world market.

The new combination of forces in the development process and the greater relative importance of the domestic market point the way to other forms of insertion of the Latin American region in the international distribution

\footnotetext{
'See Juan Ayza et al., op. cit., p. 33.
}

of labour. The force represented by the domestic market, together with the external expansion of the economies, does not aim as in the past at autarchy or at reducing the volume of imports. Imports must continue to increase in keeping with the rate of growth of the product. The real objective is to change the structure of imports and exports in order to make the growth process less vulnerable to the fluctuations of the international situation.

Nor are we thinking of a new international division of labour in which Latin America would enter the international scheme along the lines of Hong Kong or Taiwan.

The region has reached a degree of technological maturity and development of the productive processes which enable it to aspire to extend its exports to cover not only products with a high content of labour, whose cost can compete advantageously at the international level, but also to new products with a high technological content.

In this connexion, and to sum up this matter, I should like to recall some remarks by the famous economist Hollis B. Chenery:

"Any serious attempt to increase the international division of labour in manufacturing through external trade must adopt a more dynamic and longer-term viewpoint than that of the present comparative advantages if the developed countries are not to be accused of a new wave of neocolonialism. While concentration on labour-intensive products may be the only way by which a developing country can 
enter the export market, the profits made as income rises should be invested in modifying the structure of exports. In the long term, the industries in which technological progress and its future growth are most rapid need to be widely distributed among all countries, developed or not, parallel with new lines of comparative advantage - just as they are at present dis. tributed among the developed countries." 10 .

Some recent experiences by the
Latin American countries in the field of non-traditional exports are instructive as regards the type of very complex exports which the region may manage to include.

To sum up, what Latin America should do is to pursue sustained individual development at the national and regional level, increasing its efficiency and scale of operations and projecting itself vigorously towards the rest of the world so as to establish and take advantage of a new system of international division of labour.

\section{New forms of regional co-operation}

The role assigned to the regional potential described above will call for the revision of some existing mechanisms.

My intention is not to add another voice to those lamenting the stagnation of the present integration processes and in particular that of the Latin American Free Trade Association; but rather to consider that an epoch has come to an end and that it is now necessary to begin a new one, learning from past experience but never losing sight of the final objective.

This new stage cannot do without some integration mechanisms in order to establish a certain minimum framework of stimuli and discipline in the relations between the countries, with

${ }^{10}$ Hollis B. Chenery and Helen Hughes, "La división internacional de la fuerza de trabajo: el ejemplo en la industria", El Trimestre Económico, Vol. $\mathrm{xxxIX}(3)$, No 155, Mexico City, July-September 1972, p. 444. a view to laying the basis for an organized and expanded market; but it must not be limited exclusively to such mechanisms.

The wide range of bilateral agreements, bi-national or multinational interenterprise mechanisms, measures for strengthening physical unions between countries and great projects for joint execution continue to gain ground.

The emergence of new regional potentials is bound to call for novel and imaginative forms which can only come to fruition through a process of inner political conviction, which will have to be of great flexibility in order to carry out the necessary concrete action.

What has been achieved in regional interchange, although still insufficient, comes in addition to advances which may give rise to the joint exploitation of natural resources or the execution of great industrial projects.

It therefore seems that in order to 
overcome the present cases of stagnation we must take a long-term view, beginning by clearly demonstrating to all the parties the net benefits offered by their efforts, i.e., how much they can gain and at what cost. Without this it will undoubtedly be very difficult to mobilize public opinion or gain political support.

\section{The nature of the new international economic order}

The critical international economic situation, and the clear perception of the interrelations between all the aspects in crisis and of the interdependence of nations have led to an unprecedented world "negotiation explosion".

This "negotiation explosion", though sometimes apparently operating in rather a dispersed manner, has been accompanied by the historic recognition of the growing significance of the Third World and the need for a North-South dialogue in order to reach valid agreements. The promising results of the seventh special session of the United Nations General Assembly and the results expected from the Paris dialogue open up new prospects.

The stage which has now been initiated will inevitably be long and difficult. The construction of new institutions on the remains of the now out-dated Bretton Woods agreements, which fixed the rules for the world capitalist economy for the last quarter of the century, has become much more complicated. The economic aspects of international relations have been diversified through new facets which derive from the calling into question of the growth model and the life style of the central economies and have concluded with the recognition that there is a new world, with new centres and new powers, both for the traditional big central countries and for the peripheral economies.

In this connexion, some final remarks should be made.

Above all, there is a vital need to achieve Latin American unity and find suitable formulas that take account of Latin America's particular position in the new international distribution of labour which is desired and in the definition of the new rules of international life.

Latin American unity and the solidarity of the region with the rest of the Third World should go beyond the natural interest of the developing countries to act together when dealing with manifestly unequal power blocs.

Although this alone would fully justify this enterprise, there is another consideration also: namely, that the region, acting as a united whole, should deal with the special problems raised by the fact that it has beer turned into the "middle class of the modern world", thus systematically excluding it from the emergency mechanisms set up recently by the international community.

This does not mean competing for resources with regions of the world which are obviously more backward. What it does mean, however, is that there should be corresponding specific solutions for the problems of the region 
at any given time, particularly in relation to international trade or the transfer of financial resources.

A problem which affects this region very specially is that of the prices of basic commodities, which continue to be the backbone of Latin America's external trade, so that every effort must be made to organize the markets for them properly. Latin America is also concerned, however, about the access of its industrial products to markets and the terms on which technology is transferred, since both of these are aspects of fundamental importance for the present stage of the region's economic development.

The effort must be continued to ensure that the countries comply with the commitments undertaken in the United Nations as regards the transfer of resources and that stable agreement is reached on the international monetary system. At the same time, however, there must be an effort to ensure that the capital markets are opened up and access to them is facilitated so that new external savings can be absorbed by these means on normal market conditions and in competition with the developed countries. The forthcoming stages in the negotiations will be decisive in this field.

It is very important that the developing countries, suitably organized, should give certain subjects special priority. The excessive number of meetings and topics could result in priority being given to all topics, which is the same thing as not giving priority to any of them.

Primary commodities, the functioning of markets and the transfer of resources are topics of undoubted importance for Latin America, and the organization of the region in this sphere is therefore urgent and should not be put off.

CEPAL has repeated on more than one occasion that Latin America now constitutes a purchasing and selling force of no mean importance, both for increasing international trade as a whole and for the central countries themselves. It should therefore be fully aware of its bargaining power when discussing international relations.

For the United States, exports of capital goods, consumer durables and chemicals to Latin America amount to three times that country's exports to the Japantese market and almost equal its exports to the European Economic Community.

As lar as the European Economic Community is concerned, its sales of the same products to Latin America are equivalent to three-quarters of its sales to the United States market and four times its exports to the Japanese market. In 1973 the total exports of those three types of products from the United States, the European Economic Community and Japan to Latin America came to 11 billion dollars.

The bargaining power of the region is not easy to organize, but it does exist and provides a basis for a new approach based on mutual interest rather than mere concessional treatment.

It is in this new commercial spirit that the dialogue between Latin America and the other regions must be carried on, so as to put the region's international relations on a new footing. 


\section{A further consideration}

As is well known, however, the problem which Latin America is facing does not consist solely of reactivating and rearranging the set of lorces behind the region's growth. To deal with only this question would give good grounds for the accusation of an "economistic" or "developmental" distortion of the matter.

In reality, concern about this uncertain transitional period between the world of yesterday and that of tomorrow must be combined with the concern which has been growing in recent years in all our countries regarding the social projections or incidence of the modes of development which prevail in Latin America.

In other words, it is necessary not only to find means of reactivating growth but also of ensuring that the fruits of such growth are distributed more equitably. There are few people today who still feel that there is any kind of absolute or transitory conflict between the two. On the contrary, there is a growing world-wide consensus that they must be complementary and must back each other up.
It is worth recalling a few remarks made a little while ago ${ }^{11}$ :

"Of the increase of 100 dollars in the average per capita income [in Latin America ] during the 1960s, only two dollars reached the poorest twenty per cent of the population. This is clear enough proof that we cannot be proud about what has been happening in the distribution of the benefits of progress. Today there are rather more than 300 million Latin Americans. Of that number, about 100 million live in extreme poverty, and of these, some 65 million are in rural areas, cut off from markets and lacking even the minimal culture which would enable them to glimpse the possibilities of a different way of life from that which they have followed for generations".

This, then, is the dual economic and social challenge facing the region. CEPAL, faithful to the principles set forth in the United Nations Charter and to the humanistic tradition, has never forgotten that the economy must be placed at the service of mankind and of society, and not vice-versa.

\footnotetext{
"See Latin America: the new regional and world setring, op. cit.
} 